\title{
Lithuanian language intonation: history of research, in the context of language 'intonology'
}

\begin{abstract}
The linguists Jablonskis (1911) and Durys (1927) were the first to study Lithuanian language intonation. Research on intonation in other European languages (English, Russian) began earlier, in the $16^{\text {th }}$ and $17^{\text {th }}$ centuries (English: Hart (1551) and Butler (1634); Russian: Lomonosov (1743; 1765)). The beginning and the second half of the $20^{\text {th }}$ century were the most productive research periods on Lithuanian language intonation. Intonation was studied by Lithuanian linguists - syntax specialists and phoneticians. A considerable amount of research, using methods of experimental phonetics, was carried out. The main authors were the syntactician Balkevičius (1963; 1998) and the phoneticians Pukelis (1972) and Bikulčienè (1976), Pakerys (2003), Girdenis (1980; 2003).

Variants of the Lithuanian language intonation system inventory are presented in the numerous works of the author.
\end{abstract}

Keywords: intonation, experimental phonetics, intonation units, intonation system of the Lithuanian language, intonation typology.

\section{Introduction}

Intonation is a constituent part of the phonic linguistics and is perceived as linguistically universal: its features manifest themselves in all previously researched languages. Intonation is the object of research of different fields of science - psychology, psycholinguistics, physics (acustics), medicine, philology (literary studies, linguistics: phonetics, syntax, 
phonosemantics, phonostylistics), elocution and others. Recently, intonation has begun to be studied in text linguistics.

The concept of intonation, the development of intonation terminology, intonation research methods and problems in linguistics reflect the general trends of research used in other languages: from a minimalist to a considerably broader description of intonation as constituting the way a language sounds, the practice of various aspects of research (phonetic, functional), and finally the intonation system description variants, principles for determining the units of intonation system and the elements of the system.

Intonation is a means of spoken language, formed and functioning at the primary stage in the development of the language. The most general definition of intonation dates back to ancient times (in Latin (intono, intonare - pronounce loudly, speak) - in the works of Plato and Aristoxen (Ceplitis, 1974). The universality of intonation was observed, and is researched in two main aspects by many current researchers: functional - as a means of content expression, expressing the meaningful and emotional-stylistic shades of a sentence, and phonetic-acoustic - a complex of linguistic sound means, combining, „,cementing”, „binding” words into sentences as well as breaking the sentence into smaller, shorter meaningful units - syntagmas. Each syntagma is pronounced with a certain intonation characteristic of the situation, conditioned by the goals of the speaker.

Comparing the most important stages of intonation studies of Lithuanian and other languages as well as the evolution of research methods and terminology, certain general tendencies and certain (essential) differences become visible.

The first intonation studies of the Lithuanian language began much later than, for example, in the English, Russian, French, Italian, German languages, and therefore the number of researchers interested in intonation, and the number of works in Lithuanian is considerably lower. It should also be noted that, in general, intonation research is not a popular field. It is doubtful, whetherintonation has been analysed in more than thirty languages ${ }^{1}$.

The concept of elements and units of the language system, i.e. terminology, is formed during concrete studies and is finally reflected in a summarized form in some theory or as the opinion of a particular researcher about that phenomenon.

The history of intonation research shows that, in the broad sense, this phenomenon has been and continues to be similarly described in all languages. The differences in basic terminology, indicating intonation functions and its phonetic features, are relatively small.

The intonation system is still often perceived only as a contour system (more precisely, a subsystem). The determination of such intonation units (usually called intonation contours, intonation curves, intonation groups, tonemes, melodemes, intonemes, etc.) is based not on phonological laws, but on the generalisation of the intonation features of the most commonly repeated sentence types.

The aim of this article is to provide an overview of intonation research on the Lithuanian language in the context of intonation research on other languages. The research

${ }^{1}$ Most probably the only summarized work until recently is a collective monograph Intonation Systems. A Survey of Twenty Languages, Cambridge University Press, 1998: 261-274. 
method is descriptive-comparative. The research material is an overview of intonation research in Lithuanian linguistics. Intonation research in the field of literature, elocution, and communication science is beyond the scope of this article.

\section{The main part}

In this paper, intonation research on other languages (English, Russian, French, German, Italian, etc.) is relevant to work on the Lithuanian language (i. e. their research methods and findings allow comparisons to be made). In general, the beginning of intonation research on European languages and the early theorisations occurred at the end of the late Renaissance. Grammarians of that time provided the first interpretation of intonation. More significant and more detailed research was carried out only at the beginning of the $20^{\text {th }}$ century. The period until the fourth decade of the $20^{\text {th }}$ century could be described as the first ${ }^{2}$ phase of intonation research and terminology formation.

Thus, in this early (or the first) research period, the concept of intonation in all languages was traditionally based on the most perceptible sound (acoustic) intonation features, primarily the voice (tone) variation in the sentence (opposing the rising and falling tone). mMelodics of individual sentence types - direct, interrogative, exclamatory sentences were studied. It was noted that a different tone can express different semantics. The following authors and their works are distinguished as the first significant and important intonation researchers:

The beginning of English intonation studies dates back to the $16^{\text {th }}$ and $17^{\text {th }}$ centuries. The linguistic phenomenon is first mentioned in the textbooks of pronunciation by Hart (1551) and Butler (1634). Both authors associate intonation with punctuation and emphasize its phonetic aspect. More precisely, they show how the segment of speech flow can (and should) be pronounced from pause to pause. The second half of the $18^{\text {th }}$ century and the whole of the $19^{\text {th }}$ century is also a very significant stage in the English language intonation research. During this period, intonation was thoroughly examined in the textbooks of elocution, which emphasized public speaking, and intonation is considered to be a special means of aural expression and influence. One of the most famous elocutionists of that period is Walker $(1781 ; 1787)$. Another no less important time for English language intonation studies was the $19^{\text {th }}$ century, when elocution textbooks gradually began to gain popularity in America and Great Britain. Rush (1833) was one of the most prominent American elocutionists of that time; he distinguished the variation of tone in the last stressed syllable as an important feature of intonation and divided utterances into expressive and non-expressive. In the first half of the $20^{\text {th }}$ century works by Palmer (1922), Armstrong

2 There is no common (or one) opinion on the periodization of intonation studies. Volodina (2002: 11-12) offers an overview of intonation research on the Italian language. She refers to the $20^{\text {th }}$ century as the most effective period of intonation research and divides it into 5 periods. In her opinion, the most significant intonation studies of various languages were carried out in the period of 1960-1990, and especially during the last decade, after the latest computer-based intonation research methods appeared. 
(1926), Ward (1926), Pike (1945), Halliday (1967), Cruttenden (2000) and others are also significant (more about the history of English language research see Katinaite, (2010)).

The first period of Russian intonation research begins with Lomonosov (1765), later by Bogoroditsky, Peshkovsky, Shachmatov, and others (Lomonosov, 1952; Bogoroditsky, 1913; Peshkovsky 1914; Shakhmatov, 1941);

The works of Passy (1899) and Nyrop (1902), later Roude (1910) and Grammont (1925) are important for the beginnings of French intonation research;

German - Sievers (1912), Ipsen Karg (1928), Waiblinger (1925), Essen, (1940);

Italian - research material by Parmenter (1930), Hall (1948).

At the end of the early period of intonation research, the first references to the intonation of the Lithuanian language appear in the works of Lithuanian syntax specialists (Jablonskis, 1911; Durys, 1927).

Jablonskis describes types of sentences by relating them to the characteristics of voice and observes that „the speaker can express ideas directly as well as ask, be surprised.” Both Jablonskis and Durys indicate voice (tone) change as the most important feature of phonetic intonation.

The first instrumental research of Lithuanian language carried out by Swede Ekblom (1925) has to be noted. The author, aiming at determining the influence of intonation on the realization of acoustic features of accent, has examined the parameters of the main tone in direct, interrogative and imperative sentences.

The second, significant stage for intonation research, during the 1930s and 1940s, saw English, French, German, and Russian scholars continue intensive research on phonetic features and functions of sentence intonation. During this period, factual material was collected that was important for further intonation research. In addition, the basic foundations of the theory of intonation were laid: questions about functions of intonation were raised and discussed (Karsevskii 1931; Trubeckoy, 1939; 2000); the concept of syntagma, - important for intonation research - was formulated (Scherba, 1948), the phonological role of intonation opposition was discussed (Martinet, 1938; Grammont, 1938; Trubetskoy, 1939).

Trubeckoy's work Fundamentals of Phonology (Trubeckoy, 1939; 1960) laid the foundation for further studies of supersegmental (intonation) phonology.

Regarding Lithuanian intonation research, the second period has to be assessed as unproductive.

A third stage of intonation research unfolded in the 1950s and 1960s when appropriate equipment for the investigation of phonetic (acoustic) language appeared anda methodology forits application was developed. It became possible to accurately and precisely trace the smallest changes in the sound flow and intonation contour parameters. In the United States and in various European countries, a number of experimental phonetic laboratories possessing specialised equipment and scientists emerged.

This technical progress had a mixed impact on intonation research on phonetic features. Researchers tried to accurately record as many characteristic features of sentence type intonation and to identify the slightest nuances and peculiarities of the acoustic structure. However, such an approach and research methodology only increased the amount of experimental material, but did not encourage analysis. Main and secondary distinctive 
features were not identified, for instance. Research was presented without proper selection and functional analysis.

The intonation-melodic system of any language that was presented in the way was too complex, inconvenient, difficult to comprehend and difficult to apply in practice. Not without reason this method of intonation research was then reasonably criticized by many famous phoneticians and phonologists. According to Panov, in such research, all possible acoustic features were usually recorded without any selection: main and optional, supplementary, typical and individual, distinctive (differential) and non-existent (non-differentiated) (Panov, 1989: 33). Girdenis agrees with the statement: „Prosodic features determined by equipment can be published as facts of the investigated language only when they are perceived and actively used by representatives of that language for communication and when they are clearly performing a representative function. What is not understood by informants can only be a physical phenomenon, but not a fact of the language system" (Girdenis, 2003: 290).

The study of phonetic features of intonation of the Lithuanian language using methods of experimental phonetics was most intensively conducted in the 1970s and 1980s. Research was carried out based on the methodology of the Russian professor, Artiomov, that was developed in the laboratory of experimental phonetics at Foreign Languages Institute of Moscow, and adapted to intonation studies of various languages. Lasting for several years (1968-1974), active cooperation between the laboratory and the Vilnius Pedagogical Institute (leader A. Pakerys) enabled a number of intonation studies of the Lithuanian language to be carried out.

Research carried out using the oscillographic method was used to determine phonetic features of intonation in specific sentence types, for example, Bikulčienè studied intonation of imperative sentences (Bikulčienè, 1976; 1978; 1982). Pukelis studied intonation of general questions (Pukelis, 1968; 1972a; 1972b), Statkevičienè (1972; 1976) analysed phonetic features of homogeneous and heterogeneous attributes; Talandienè - acoustic features of alternative questions (Talandienè, 1970). The most significant works were the doctoral dissertations by Pukelis (1972) and Bikulčienè (1976).

The most significant studies on Lithuanian language intonation were conducted in the final four decades of the $20^{\text {th }}$ century. This is, conditionally, the fourth stage of intonation research. During this period, syntax specialists analysed and pointed out the most important functions performed by intonation; phoneticians conducted the most important experimental studies and published their results Using the complex phonological method, the intonation system of the Lithuanian language was established.

Among syntax specialists, perhaps Balkevičius in his work focused on intonation most of all. In the textbook Syntax of the Present Lithuanian Language (1963), quite a lot of valuable information was provided. This include the functions of intonation and its phonetic features. The author, using only the audio method, describes the main intonation acoustic components, distinguishes the most important of them - tone, duration, intensity, timbre, etc.. Balkevičius shows the peculiarities of their interaction in different types of sentences, and refers to the functions of other, in his opinion, intonation-specific means of syntagmatic fragmentation - logical (or phrase) stress and pause. 
In another work, The Syntax of the Predicative Structures of the Lithuanian Language (1998), J. Balkevičius notes that "some of the non-grammatical language means often help sentence predication to be finally unclosed - the most important of which are sentence intonation and word order." (Balkevičius, 1998: 46 ) Intonation, in his opinion, "helps the speaker to more precisely and more impressively vocally express relationships that are formally already encoded in the lexical meanings of the words and their grammatical forms, $[\ldots]$ it can change the direction of grammatical connection or modify the meanings of semantic relations when their difference is not indicated by grammatical means." (ibid.)

Balkevičius also mentions the emotional function of intonation when,,intonation reveals to the listener such emotions of the speaker as well as modal shades of audible content, for which there is no lexical expression" (Balkevičius, 1998: 46).

Academic Grammar of the Lithuanian Language (1976) and The Current Grammar of the Lithuanian Language (1994) describe intonation only as an auxiliary means of syntactic relations' in various sentences: in simple sentences, dividing them into modal types (direct, imperative, interrogative and exclamatory); in complex compound sentences "the clauses of which are connected by intonation and syndetic words" (DLKG, 1994: 658); in asyndetic sentences, "clauses are joined by intonation only" (ibid.), and the meaning of „meaningful relations of clauses become clear only from intonation” (DLKG, 1994: 720). Accordingly, for these sentences, [...] there are four types of intonation: enumerating, contrastive, conditional and supporting intonation" (DLKG, 1994: 721). It is important to note that intonation, as phonetic, supersegmental (prosodic) language element (or phenomenon), is not generally considered in these grammars. Acoustic intonation components, its phonetic features and intonations, as functions expression means, structure is not shown, only "special”, ,specific”, ,special interrogative” or „exclamatory” intonation of modal sentence types is discussed (DLKG, 1994: 573-581).

Lithuanian phoneticians (their publications are not abundant) give very little information about intonation. Mikalauskaite briefly describes intonation in the book The Phonetics of the Lithuanian Language (Mikalauskaite, 1975) ${ }^{3}$, examining its phonetic features and performed functions alongside with sentence stress and rhythm (Mikalauskaite, 1975: 81-84, 146-150). Her important conclusion is that "sentence stress is not equivalent to word stress", "sentence stress is a more notional matter [...] it should be examined not only in phonetics but also in semantics which is more concerned with the language notional side" (Mikalauskaite, 1975: 146). The author also observes that "sentence stress can be analysed in another respect, namely, in relation to rhythm and melody." (ibid.)

The most famous phoneticians in Lithuania, Pakerys and Girdenis analyse intonation in their works, "only to the extent that it relates to the supersegmental elements of the word" (Pakerys, 1982: 5; Girdenis, 2003: 240).

Only in Pakerys' last work, Phonetics of the Lithuanian National Language (Pakerys, 2003), is more attention paid to phrase intonation (ibid: 231-235). At the moment, this is

3 As written in the preface to „Phonetic Works of Lithuanian Language”, a compilation of unpublished studies of Mikalauskaite: lectures on phonetics of the Lithuanian literary language, description of phonetics of the native dialect and experimental works (Mikalauskaitè, 1975: 3). 
probably the only source where information about the intonation of the Lithuanian language can be found. The author identifies the main functions of intonation, its most important phonetic features, possible pronunciation mistakes, and methods of intonation marking in the written form of the language. He notes that intonation finally forms a minimum unit of spoken language - the sentence. The sentence (phrase) may consist of one or more syntagmas. Intonation is an important tool for expressing relationships between phrase components (syntagmas), ,sometimes it is the most important way of this expression" (Pakerys, 2003: 232). As an important feature of intonation from the functional point of view, the author indicates syntagmatic stress: the word accented by this stress specifies the meaning of the utterance and can be perceived as a logical or phrase stress. According to the purpose of the utterance, ,phrase intonation can be described in several aspects: intellectual, imperative and emotional” (Pakerys, 2003: 231). In general, his opinion in this regard coincides with the opinion of Girdenis that intonation „conveys the intellectual (material) content of the utterance, as well as performs expressive (emotional) and appellative functions" (Girdenis, 2003: 36-39).

Girdenis is the author of the article on intonation in The Encyclopaedia of the Lithuanian Language (1999). As is typical of encyclopaedias, the most important data about intonation of the Lithuanian language - its acoustic features and its functional capabilities that are attributable directly and indirectly to intonation - are presented concentrically.

More theoretical information about intonation as a supersegmental prosodic element of the language is given in Girdenis's Theoretical Foundations of the Lithuanian Phonology (Girdenis, 2003), although there is no separate section analysing intonation. This is most probably due to the fact that according to Girdenis, "even taken separately intonation is a very complicated phenomenon. It combines elements of expression and content, representational and expressive function of sounds, even purely linguistic and so-called paralinguistic phenomena"4. Therefore, it is not phonology that is usually interested in the discussed intonation phenomena but the previously mentioned (\&17) complex discipline 'intonology' (see: Svetozarova, 1982: 14), which deals with language melody, dynamics and tempo of speech in relation to various functions (see: Ceplitis, 1974 and min lit.). The most related part of these studies to phonology is sometimes called "sentence phonetics or sentence phonology" (Girdenis, 2003: 239-240).

Although implicitly, the problems of intonation research are described in detail in the first introductory chapter of this book, where the author clarifies the basic concepts of phonological science, and in the fourth, which describes the supersegmental elements of the language. Girdenis emphasizes the exceptional importance of the latter in the language system and their close relation with the segmental elements: "[...] neither phonemes nor words can exist without supersegmental elements, since only they transform phoneme syllables and word combinations into real sentences and utterances [...]. The sentence without intonation is impossible in the same way as it is impossible without words"

${ }^{4}$ As Girdenis points out in the footnote, non-verbal phenomena and signs called as paralinguistic elements follow speech acts: gestures, mimics, specific general tone of voice (for example, its tenderness, roughness, absolute height range, clutter, etc. (Girdenis, 2003: 239)). 
(Girdenis, 2003: 239). It is necessary to emphasize that the statements, comments and conclusions presented by Girdenis are based on numerous references to the works of many of the world's most famous phoneticians, phonologists and other scientists that have been analysing similar problems...

As Pakerys points out, in the Lithuanian language, functional intonation description has old linguistic traditions, thus, "various intonation questions are analysed on a functional basis" (Pakerys, 2003: 231). In terms of functionality, intonation in Lithuanian is described as a means of sentence (phrase) content expression. It conveys intellectual (objective) content of the utterance, as well as performs expressive (emotional) and appellative functions.

The definition of intonation given by Girdenis in The Encyclopaedia of the Lithuanian Language emphasizes its phonetic basis and describes it as "a complex of sound means processing the sentence or the phrase of the spoken language" (LKE, 1999: 259). In this article, the author further mentions intonation functions.

Systematic intonation research using the complex-phonological method wascarried out by Kundrotas (1983-2018). It has been found that the intonation system of the Lithuanian language consists of four elements: 1) the subsystem of 7 units of intonation types; 2) the shift of the intonation centre (marking of intonation centre); 3 ) the syntagmatic spread and pause as an additional element the syntagma. The intonation system is a constituent part of the whole language phonetic (phonological) means.

\section{Conclusions}

The objectives of intonation research are relevant to each language individually, and the results of the research are the intonology of that language, which in turn complements and collectively forms the concept of general linguistics (theory and practice).

In this way it is possible to determine the general (universal) and specific features of the Lithuanian language intonation, its functions, means of expression and typological properties.

Summarizing research on intonation of Lithuanian and other languages, it can be argued that intonation was most often investigated either in functional or phonetic terms. Depending on approach, the definition of intonation emphasizes either its functions, or its phonetic features.

Using the complex phonological method, the intonation system of the Lithuanian language was established.

\section{References}

Armstrong L.E., Ward I.C. (1926), Handbook of English intonation, Teubner, Leipzig and Berlin.

Balkevičius J. (1963), Dabartinès lietuviu kalbos sintaksè, Vilnius.

Balkevičius J. (1998), Lietuviu kalbos predikatinių konstrukciju sintaksè, Vilnius. 
Bikulčienė P. (1970), Skatinamosios intonacijos suvokimas, Vilnius.

Bikulčienė P. (1976), Lietuviu kalbos skatinamoji intonacija. (Eksperimentinis fonetinis tyrimas), Filologijos mokslų kandidato disertacija, Vilnius.

Butler C. (1634), The English grammar, or the institution of letters, syllables and words in the English tung, Oxford. Reprinted in A. Eichler (ed.), 1910, Charles Butler's grammar, Max Niemeyer, Halle.

Cruttenden A. (2000), Intonation, First edition 1986, Cambridge University Press.

DLK [Dabartinès lietuvių kalbos gramatika] (1994), Vilnius.

Girdenis A. (2003), Teoriniai lietuviu fonologijos pagrindai, Vilnius.

Grammont M. (1925), L'acent d’insistance, [in:] Melanges publies en l’honneur de M. Paul Boyer, Libraire ancienne H Champion.

Halliday M.A.K. (1967), Halliday, Intonation and grammar in British English, Mouton, The Hague.

Hart J. (1551), The opening of the unreasonable writing of our inglish toung, London. Reprinted in B. Danielson (ed.), John Hart's work on English orthography and pronunciation, 1569, Almquvist and Wiksell, Stockholm.

Durys M. (1927), Lietuvių kalbos sintaksè, Kaunas.

Ekblom R. (1925), Quantität und Intonation im Chochlitauschen, Uppsala.

Essen O. (1940), Melodische Bewegung der Sprechstimme in deutschen Mundarten, Forschg. Fortschr.

Intonation Systems. A Survey of Twenty Languages (1998), edited by Daniel Hirst and Albert Di Cristo, Cambridge University Press, 261-274.

Ipsen u. Karg. Schallanalytische Versuche. Heidelberg.1928.

Jablonskis J. (1911), Rygiškiu Jono lietuviu kalbos sintaksè, S-P.

Katinaitė E. (2010), Anglu kalbos intonacija: tyrimo istorija, dabartis ir perspektyvos. Žmogus ir žodis. Svetimosios kalbos. Mokslo darbai, Vilnius, t. 6, no. 1. p. 19-27.

Kundrotas G. (2000), Garsinès teksto raiškos priemonès rusų ir lietuvių kalbose // Žmogus ir žodis. Svetimosios kalbos. Mokslo darbai, Vilnius, t. 2, no. 3, p. 3-11.

Kundrotas G. (2004), Lietuvių kalbos intonacija: teorija ir praktika. Žmogus ir žodis. Didaktiné lingvistika. Mokslo darbai, Vilnius, t. 6, no. 1, p. 13-19.

Kundrotas G. (2008), Lietuvių kalbos intonacinių kontūru fonetiniai požymiai (eksperimentinis-fonetinis tyrimas). Žmogus ir žodis. Didaktine lingvistika. Mokslo darbai, Vilnius, t. 10, no. 1, p. $43-55$.

Kundrotas G. (2009), Lyginamoji lietuviu ir rusų kalbu intonaciniu sistemu analizè, Vilniaus pedagoginio universiteto leidykla, Vilnius.

Kundrotas G. (2012), Intonacine tipologija, Lietuvos edukologijos universiteto leidykla, Vilnius.

Kundrotas G. (2018), Lietuvių kalbos intonacine sistema (sisteminis-tipologinis tyrimo aspektas), Utena.

LKE [Lietuviu kalbos enciklopedija] (1999), Vilnius. 
LKG [Lietuviu kalbos gramatika], (1976). Vyr. red. K. Ulvydas. Vilnius.

DLKG [Dabartinés lietuviu kalbos gramatika] (1994), Vilnius.

Martinet A. (1980), Elements de linguistique generale, P. Colin (1 ed. - 1960).

Mikalauskaitė E. (1975), Lietuviu kalbos fonetikos darbai, Vilnius.

Nyrop K. (1934), Manuel de phonetique du francais parle, $5^{\text {th }}$ ed., Copenhague.

Pakerys A. (1982), Lietuviu bendrinès kalbos prozodija, Vilnius.

Pakerys A. (2003) Lietuviu bendrinès kalbos fonetika, Vilnius.

Palmer H.E. (1922), English intonation with systematic exercises, Heffer, Cambridge.

Pike K.L. (1945), The intonation of American English, Ann Arbor: University of Michigan Press.

Pukelis V. (1972b), Dabartinès lietuviu kalbos patikrinamojo klausimo intonacija. (Eksperiè mentinis fonetinis tyrimas). Filologijos mokslų kandidato disertacija, Kaunas.

Rush J. (1833), The philosophy of the human voice, embracing its psychological history together with a system of principles by which criticism in the art of elocution may be rendered intelligible. Second edition, Grigg and Elliot, Philadelphia.

Statkevičienè J. (1972), Vienarūšiu ir nevienarūšiu pažyminiu trukmè, Vilnius.

Statkevičienė J. (1976), Vienarūšiu ir nevienarūšiu pažyminiu intonacijos suvokimas // Fonetine kalbos sandara, Vilnius.

Talandienė M. (1970), Alternatyvvinių klausimų loginiai ir komunikaciniai santykiai // Kalbos garsai ir intonacija, Vilnius.

Trubeckoj N. (1939), Grundzuge der Fonology, Gottingen.

Waiblinger E. (1925), Tonfall deutscher Mundarten, Vox.

Walker J. (1781), Elements of elocution, Reprinted by The Scolar Press.

\section{Streszczenie Intonacja języka litewskiego: historia badań w kontekście intonologii języka}

Badania nad intonacją języka litewskiego po raz pierwszy odnotowano dopiero na początku XX wieku w pracach językoznawców Jablonskisa (1911) i Durysa (1927). Pierwsze badania nad intonacją innych języków europejskich (angielski, rosyjski) sięgają XVI i XVII wieku (angielski: Hart (1551) i Butler (1634); rosyjski: Łomonosow $(1743 ; 1765))$.

Najbardziej produktywny okres badawczy to początek i druga połowa XX wieku, kiedy intonację języka litewskiego badali lingwiści litewscy - specjaliści z zakresu syntaktyki oraz fonetyki. Przeprowadzono znaczną część badań z wykorzystaniem metod fonetyki eksperymentalnej. Główni autorzy - syntaktyk Balkevičius (1963; 1998), fonetycy Pukelis (1972) i Bikulčienè (1976), Pakerys (2003), Girdenis (1980; 2003).

Warianty inwentaryzacji systemu intonacji języka litewskiego przedstawiono w licznych pracach autora artykułu.

Slowa kluczowe: intonacja, fonetyka eksperymentalna, jednostki intonacyjne, system intonacji języka litewskiego, typologia intonacji. 